\title{
The Role of Strategic Flexibility in The Associations between Management Control System Characteristics and Strategic Change
}

\author{
Mark Srour \\ Macquarie University \\ E-Mail: mark.srour@gmail.com \\ Kevin Baird \\ Macquarie University \\ E-Mail: kevin.baird@mq.edu.au \\ Herb Schoch \\ Macquarie University \\ E-Mail: herb.schoch@mq.edu.au
}

\begin{abstract}
The research question addressed in this paper is this: what is the role of strategic flexibility as a product of MCS characteristics, an enabler of strategic change, and a mediating variable in the relationships between MCS characteristics and strategic change? This focus fills a gap in the literature which in the past has reported research primarily on the nexus between MCS characteristics and strategic change. Data are collected through a mail-based survey of strategic business units in Australian manufacturing organizations. The findings indicate that two MCS characteristics (the timeliness and interactive use of information) lead to strategic flexibility, that strategic flexibility leads to strategic change (operational change), and that strategic flexibility mediates the relationships between these particular MCS characteristics and strategic change. The study's findings offer a more comprehensive theory of strategic management in dynamic environments, which contributes to the MCS-strategy literature and informs the practice of organizational management with reference to the resource-based view of the firm. In particular, the findings indicate to researchers in the MCS-strategy field that, although some MCS characteristics might lead directly to strategic change, greater attention should be paid to the role of strategic flexibility as a
\end{abstract}


product of MCS characteristics, an enabler of strategic change, and a mediator in the relationships between certain MCS characteristics and strategic change.

Keywords: Management Control Systems, Strategic Flexibility, Strategic Change

\section{INTRODUCTION}

Organizations are facing omnipresent external pressure to continually reconsider their strategic positions and, whenever appropriate, engage in strategic change (Danneels, 2002). While researchers have considered how various organizational factors support organizational effectiveness in dynamic environments through the facilitation of strategic change (Chenhall and Langfield-Smith, 2003; Abernethy and Brownell, 1999; Simons 1995, 1994, 1991, 1990), scant attention has been given to the role of strategic flexibility in that facilitative process as a product of organizational factors and an enabler of strategic change. This study reconceptualizes the facilitative process by examining whether there is an interposition of strategic flexibility in the relationship between specific management control system (MCS) characteristics and strategic change. Specifically, the study examines the associations between MCS characteristics (information characteristics including the scope, timeliness, aggregation and integration of information, and the interactive use of information) and strategic flexibility and between strategic flexibility and strategic change and also explores whether strategic flexibility mediates the associations between specific MCS characteristics and strategic change. The study's findings indicate that two MCS characteristics (the timeliness and interactive use of information) lead to strategic flexibility, that strategic flexibility leads to strategic change (operational change), and that strategic flexibility mediates the relationships between these particular MCS characteristics and strategic change.

\section{Strategic Change}

Some researchers have adopted a narrow view of strategic change as the practice of encompassing change in strategic positions along a strategy (prospector-defender) continuum (e.g., Naranjo-Gil and Hartmann, 2007; Abernethy and Brownell, 1999; Shortell and Zajac, 1990). However, this study recognizes that strategic change entails the (re)alignment of organizational strengths and weaknesses with prevailing environmental opportunities and threats (Hrebiniak and Joyce, 1985, 1984; Bedner et al., 2012) and therefore relates formal and informal changes to strategy as well as the consequences of their implementation (i.e., changes to resource allocations and to organizational systems, processes, and activities) (Zhang and Rajagopalan, 2010; 
Wiersema and Bantel, 1992; Greiner and Bhambri, 1989; Jaeger and Baliga, 1985). These changes can be initiated by top management or emerge from day-to-day actions throughout the organization and can be relatively insignificant or otherwise so significant that they redefine an organization's strategic trajectory (Davila, 2005).

\section{Strategic Flexibility}

Since to date there has not been a proven agreed-upon definition of strategic flexibility (Roberts and Stockport, 2014), it follows that definitions of strategic flexibility vary greatly with respect to the particular fields in which they are applied. Their common foundation is their reference to the quality of being 'ready and able to change so as to adapt to different circumstances,' or being 'able to be easily modified to respond to altered circumstances or conditions' (New Oxford American Dictionary, 2005). This study defines strategic flexibility as comprising a deliberately and strategically crafted organizational capability (MacKinnon, Grant, and Cray, 2008), providing for timely response and adaptation (Shimizu and Hitt, 2004; Buckley and Casson, 1998; Matusik and Hill, 1998; Das and Elango, 1995) to environmental changes that are so substantial as to meaningfully impact organizational performance (Akhtar and Mittail, 2014; Cingoz et al., 2013; Kandemir and Acur, 2012; Schoen, 2012; Shimizu and Hitt, 2004; Aaker and Mascarenhas, 1984).

The paper is hereafter organized as follows. Section two reviews the literature and develops the hypotheses. Section three details the research method, the data collection process, and the measurement of variables. Section four presents the results, and Section five discusses their implications. Section five also discusses the study's contributions and limitations and avenues for future research arising therefrom.

\section{THEORY AND HYPOTHESES DEVELOPMENT}

In the face of increasingly dynamic economic landscapes defined by increasingly frequent, swift, and uncertain change, organizations have come to recognize the value of flexibility, responsiveness, and innovation both in the private sector, due to the effects of globalisation, technological advancements, and shifts in consumer preferences (Hitt, Keats, and DeMarie, 1998; Bettis and Hitt, 1995), and in the public sector, due to the proliferation of contemporary public management paradigms (Modell, 2004; Kaul, 1997).

In this context, reliance on methods of strategic management traditionally employed in stable environments may bind organizations to narrow strategic foci and lead them into organizational decline caused by the 'failure to adapt or change to fit external environmental demands' (Weitzel and Jonsson, 1989: 94). In designing their 
organizations to withstand the rigors of maintaining organizational effectiveness in dynamic environments, managers ought to focus less on the execution of strategic change per se and more on the development and management of certain organizational resources (e.g., MCS characteristics) and capabilities (e.g., strategic flexibility) that promote long-term competitive advantage through the facilitation of shorter-term (re)alignments of organizational strengths and weaknesses with prevailing environmental opportunities and threats (i.e., strategic change) (Singh et al., 2012; Drnevich and Kriauciunas, 2011; Eisenhardt and Martin, 2000; Teece, Pisano, and Shuen, 1997).

Strategic flexibility is widely recognized as a distinct competitive advantage (Dwyer et al., 2013; Hitt et al., 1998; Volberda, 1998; Sanchez, 1997b, 1995; Lau, 1996; Garud and Kotha, 1994) as an issue of systematic difference between organizations (Lant and Montgomery, 1987). It is also an aspect organizations probably find too difficult to imitate (Sanchez, 1995) and one on which organizational performance is significantly dependent (Arief et al., 2013; Liu et al., 2013; Kandemir and Acur, 2012; Nadkarni and Herrmann, 2010; Nadkarni and Narayanan, 2007; Abbott and Banerji, 2003; Worren, Moore, and Cardona, 2002; Grewal and Tansuhaj, 2001) at various levels of environmental dynamism (Cingoz et al., 2013; Yongsun, 1992). As Zhang (2005) explains, strategic flexibility confers competitive advantage at different levels of the organization: at the functional or tactical level, it facilitates the utilisation of value-creating operational strategies, such as just-in-time inventory and mass customisation (Byrd, 2001; Kotha, 1995; Treacy and Wiersema, 1993; Stalk, Evans, and Shulman, 1992); at the strategic business unit (SBU) level (that with which this study is concerned), it facilitates transitions between business-level strategies and conditions the organization toward sustainable, long-term alignment with the environment through continual change and improvement in processes and technologies and continual organizational learning (Helfat et al., 2007; Teece et al., 1997; Goldhar and Lei, 1995; Hayes and Pisano, 1994).

This study aims to contribute to the literature and inform the practice of organizational management in a number of ways. First, examination of the association between strategic flexibility and strategic change permits insight into the role of strategic flexibility as an enabler of strategic change. Secondly, examination of the associations between specific MCS characteristics and strategic flexibility facilitates insight into the role of strategic flexibility as a product of MCS characteristics and the value of MCS characteristics as antecedents to strategic flexibility. Furthermore, exploratory analysis permits insight into the role of strategic flexibility as a mediating 
variable in the relationships between MCS characteristics and strategic change. The study's hypotheses are developed below and summarized in Figure 1.

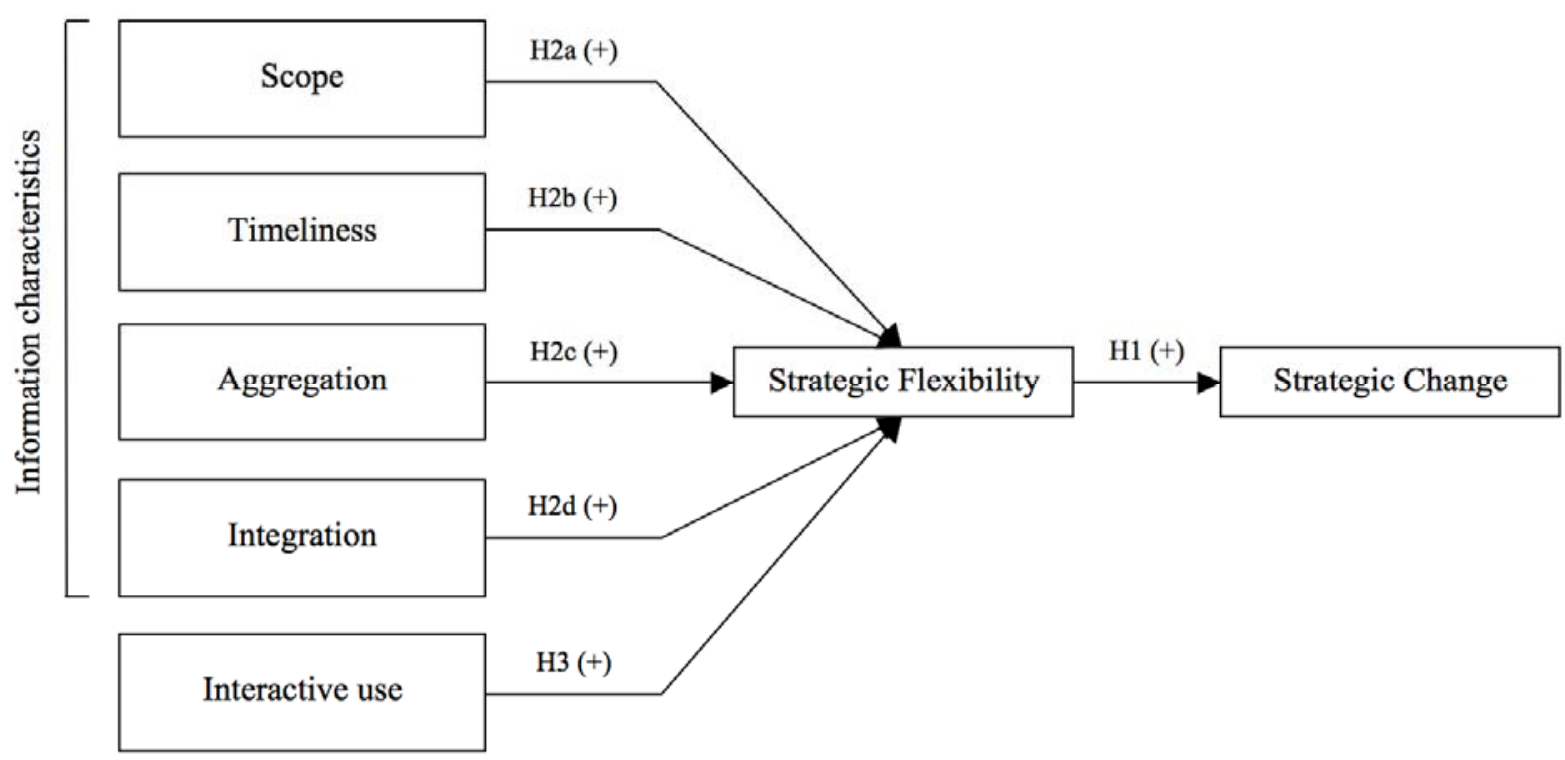

Figure 1 Summary of The Hypotheses

\section{Strategic Flexibility and Strategic Change}

A dominant theme in the literature is how strategic change occurs, including who initiates it and what factors constrain and facilitate it (e.g., Herrman and Nadkarni, 2014; MacKay and Chia, 2013; Naranjo-Gil and Hartmann, 2007; Abernethy and Brownell, 1999; Wiersema and Bantel, 1992; Kelly and Amburgey, 1991; Greiner and Bhambri, 1989). While the literature has largely focused on MCS characteristics as direct determinants of strategic change (e.g., Naranjo-Gil and Hartmann, 2007; Abernethy and Brownell, 1999; Wiersema and Bantel, 1992), Henri (2006b) argues that the link between MCS and strategy exists at the capabilities level rather than at the strategic choice level. Accordingly, we suggest that strategic change is facilitated by, and to some degree contingent upon, strategic flexibility, thus the value of which by definition lies in its facilitation of continual and timely strategic change. Our emphasis on the significance of organizational capabilities to sustained organizational alignment with the environment (Helfat et al., 2007; Teece et al., 1997) accords with the resource-based view of the firm and, in particular, the literature suggesting that organizations are less likely to change and adapt in the absence of those capabilities (e.g., Sharfman and Dean, 1997; Mintzberg and McHugh, 1985). 
The role of strategic flexibility as an enabler of strategic change has not been previously examined empirically, having apparently been taken for granted as axiomatic. Arguably, such a role can be inferred from empirical evidence supporting positive associations between strategic change and organizational performance (Baum and Wally, 2003; Virany, Tushman, and Romanelli, 1992; Smith et al., 1991; Smith and Grimm, 1987) and between strategic flexibility and organizational performance (Abbott and Banerji, 2003; Grewal and Tansuhaj, 2001; Yongsun, 1992). The inference is appropriate on the premise that flexible organizations (especially those operating in dynamic environments) must effectively change or adapt to prevailing environmental opportunities and threats in order to achieve high performance. The validity of this premise is widely supported by case study evidence. For example, Aaker and Mascarenhas (1984) show how flexibility allowed an American manufacturer to avoid the adverse effects of changing technology and increasing international manufacturing costs by changing suppliers and the country of manufacture (see also Hatch and Zweig, 2001).

Sharfman and Dean (1997) argue that, although flexibility in strategic decision making (a core component of an organization's strategic flexibility (Combe and Greenley, 2004; Sharfman and Dean, 1997) will not always result in change or adaptation (e.g., due to implementation problems or a lack of environmental change), only rarely will organizations adapt in the absence of such flexibility. The same can be said in relation to flexibility more generally (Teece et al., 1997; Mintzberg and McHugh, 1985). Change can conceivably take place without the characterisation of an organization as strategically flexible (e.g., management teams may execute change irrationally and without the inducement of environmental stimuli). However, by definition, strategic flexibility is realized through actual strategic change in the process of organizational adaptation to a changed environment. In this sense, it is plausible that strategic flexibility enables and facilitates the realisation thereof, such that flexible organizations are more likely to engage in strategic change in response to environmental stimuli, whereas inflexible organizations are less able to do so and more likely to be inert.

H1: The degree of strategic flexibility is positively related to the degree of strategic change.

\section{Specific MCS Characteristics and Strategic Flexibility}

While empirical research on the relationships between MCS characteristics and strategy has largely focused on the organization's engagement in strategy (re)formulation and strategic change (e.g., Naranjo-Gil and Hartmann, 2007; 
Abernethy and Brownell, 1999; Wiersema and Bantel, 1992), this study is concerned with how MCS characteristics impact strategic flexibility: the strategic organizational capability to identify, respond, and successively adapt in a timely fashion to substantial changes in the external environment. In doing so, the study shifts the primary analytical focus from the strategic-choice level to the capabilities level (Grafton, Lillis, and Widener, 2010; Henri, 2006b). This approach accords with the resource-based view of the firm, which suggests that competitive advantage is driven by the effective development and management of resources and capabilities controlled by a firm: in particular, while resources (e.g., MCS characteristics) define a firm's capabilities, those capabilities (e.g., strategic flexibility) are the main drivers of competitive advantage through the materialisation of strategic choices (i.e., strategic change) (Chenhall et al., 2011; Grant, 1991; Henri, 2006b).

The proposition that MCSs can facilitate the achievement of strategic flexibility is a plausible one, proffered by a number of scholars (e.g. Gond et al., 2012; Shimizu and Hitt, 2004; Volberda, 1998; Sanchez, 1997a, 1995) and evidenced by case studies (e.g., Jaeger and Baliga, 1985). MCSs consist of formal and informal tools and processes used by managers to influence members of an organization toward achievement of the organization's strategic objectives (Anthony and Govindarajan, 2007). In this study, specific MCS characteristics (information characteristics, including the scope, timeliness, aggregation, and integration of information and the interactive use of information) are directly related to strategic flexibility. The chosen MCS characteristics are malleable ones, over which management teams generally have control and which can be strategically engineered and utilized so as to facilitate the development of organizational capabilities. Moreover, some of these characteristics have been studied with respect to their relationships with other aspects of strategy, including strategic change (e.g., Naranjo-Gil and Hartmann, 2007; Abernethy and Brownell, 1999), and are recognized as determinants of strategic flexibility (e.g., Hitt et al., 1998; Volberda, 1998; Lei, Hitt, and Goldhar, 1996; Sanchez, 1995; Upton, 1995).

\section{Information Characteristics}

Information gaps (differences between the available information and that required to make a decision) entail uncertainty (Galbraith, 1973), which impedes decision making and thus restricts flexibility (Zhang 2006, 2005; Shimizu and Hitt, 2004; Bouwens and Abernethy, 2000). Information has a 'decision-facilitating function' within organizations (Bouwens and Abernethy, 2000: 223; O'Reilly, 1983), and the characteristics of available information can affect the performance of various 
strategy-relevant tasks (Gordon and Miller, 1976), including strategy formulation and implementation (Bhimani and Langfield-Smith, 2007; Chenhall and Langfield-Smith, 1998). Hence, information and the processing thereof are inextricably linked to strategic flexibility (Combe and Greenley, 2004; Sharfman and Dean, 1997).

Researchers have examined the decision-facilitating function of information with reference to the scope, timeliness, aggregation, and integration of information (Naranjo-Gil and Hartmann, 2007; Bouwens and Abernethy, 2000; Mia and Chenhall, 1994; Chenhall and Morris, 1986; Gordon and Narayanan, 1984; Larcker, 1981). These characteristics are hereafter individually related to strategic flexibility.

Measured on the dimensions of focus, quantification, and time horizon, 'narrow scope' information is internally focused, financial, and historically based, whereas 'broad scope' information is also externally focused, non-financial, and futureorientated (Ittner, Larcker, and Randall, 2003; Bowens and Abernethy, 2000; Chenhall and Morris, 1986; Gordon and Narayanan, 1984; Larcker, 1981).

Naranjo-Gil and Hartmann (2007) present empirical evidence of a positive relationship between broad-scope information and the extent of strategic change. With regard to the more immediate and direct effect on decision-making capabilities (and thus strategic flexibility), broad-scope information encourages and facilitates environmental scanning behavior for the identification and informed assessment of strategic issues (Vandenbosch and Huff, 1997); the formulation of solutions and decision making on the basis of information that has greater predictive ability and is more timely, actionable, and directly traceable to strategic actions (Larcker, 1981); decentralisation for the empowerment of lower-level personnel to take action (Gerdin, 2005); and organization-wide dialogue and debate and interdepartmental planning and coordination, which focus attention on strategic issues and foster the emergence of viable courses of action that are consistent with the objectives of interdependent SBUs (Naranjo-Gil and Hartmann, 2007; Henri, 2006a; Bouwens and Abernethy, 2000; Amason, 1996; DeDreu, 1991; Tjosvold, 1991).

Hence, broad scope information can reduce the uncertainty that impedes strategic decision making and restricts flexibility because it can target specific sources of uncertainty, which are often external to the organization, not easily measureable in financial terms, and likely to fully materialize in the future.

$\mathrm{H} 2 \mathrm{a}$ : Broad (narrow) scope information is positively (negatively) related to strategic

\section{Flexibility}


The timeliness of information refers to both the frequency and speed of information reporting (Bouwens and Abernethy, 2000; Chenhall and Morris, 1986). By reporting on the most recent events and providing rapid feedback about decisions, timely information can reduce uncertainty and allow decision makers to quickly and continually adjust activities in response to environmental changes as soon as they occur (Bouwens and Abernethy, 2000; Chenhall and Morris, 1986).

Timely organizational adaptation to environmental change is central to the definition of strategic flexibility adopted in this study. A recurring theme in the literature is the importance of strategic flexibility of information systems and technologies (such as electronic data interchange) that provide real-time data, allowing decision makers to identify and address emerging opportunities and threats sooner than otherwise possible (MacKinnon et al., 2008; Zhang, 2005).

$\mathrm{H} 2 \mathrm{~b}$ : The timeliness of information is positively related to strategic flexibility.

Aggregated information refers to information summarized by functional area or time period or through decision models such as discounted cash flow analyses and incremental/marginal analyses (Bouwens and Abernethy, 2000; Chenhall and Morris, 1986). The aggregation of information supports strategic flexibility by increasing a decision maker's information processing capacity and thereby helping to avoid suboptimal decision making due to information overload (Ackoff, 1967). By allowing the decision maker to develop a better understanding of input-output relations within and across departments, the decision maker can consider more alternative solutions to strategic issues and adopt the solutions that are best for the organization as a whole (Bouwens and Abernethy, 2000).

$\mathrm{H} 2 \mathrm{c}$ : The aggregation of information is positively related to strategic flexibility.

Integrated information details the activities of other SBUs and indicates how the decisions made in one SBU may influence the performance of other SBUs or the respective departments that constitute it. This information could be related to inputs, outputs, technologies, and operating processes employed by the SBUs (Bouwens and Abernethy, 2000).

As interdependencies between SBUs increase, ${ }^{1}$ the decisions made in one SBU increasingly affect the outcomes of decisions made in other SBUs, and vice versa. Integrated information helps to ensure that the uncertainties otherwise induced by interdependencies neither arise nor impede strategic decision making (Bouwens and

\footnotetext{
${ }^{1}$ Interdependence, in this context, refers to the degree to which SBUs or departments therein depend upon each other in order to accomplish tasks (Thompson, 1967).
} 
Abernethy, 2000; Gordon and Miller, 1976). Indeed, the integration of information facilitates strategic decision making and thereby leads to strategic flexibility. By allowing decision makers to effectively evaluate trade-offs among alternative courses of action, integrated information leads to the generation of viable strategic ideas that are suited to and maintain strategic and operational coordination between interdependent subunits (Bouwens and Abernethy, 2000; Atkinson et al., 1997; Walton and Dutton, 1969).

$\mathrm{H} 2 \mathrm{~d}$ : The integration of information is positively related to strategic flexibility.

\section{Interactive Use of Information}

Information can be used in either a diagnostic or interactive manner. When information is used diagnostically, it is used on an exception basis as formal feedback to monitor organizational outcomes relative to predetermined expectations and to address deviations therefrom (Henri 2006a, 2006b; Abernethy and Brownell, 1999; Simons, 1995, 1994). Diagnostic use is thus particularly useful for monitoring and coordinating the effective implementation of chosen strategies (Kober, $\mathrm{Ng}$, and Paul, 2007; Henri, 2006b). Interactive use implies an increased and recurrent flow of information throughout the organization as well as loose and informal control emphasising cooperation, face-to-face communication, and action among decision makers at all levels and across functional areas (Widener, 2007; Henri, 2006b; Bisbe and Otley, 2004; Abernethy and Brownell, 1999; Simons, 1987; Galbraith, 1977; Burns and Stalker, 1961).

The significance of the interactive use of information in organizations is evidenced by case studies demonstrating the importance of the free flow of information and organization-wide strategic dialogue and debate in the enablement and facilitation of strategic change (Kober et al., 2007; Archer and Otley, 1991; Roberts, 1990) and by empirical research indicating a positive relationship between interactive use and specific organizational capabilities that lead to strategic decision making (namely, market orientation, entrepreneurship, organizational learning, and innovativeness) (Henri, 2006b).

Interactive use is an important means by which top managers' strategic priorities (such as flexibility) are revealed and communicated to the rest of the organization (Simons, 1991). The consequent stimulation of organization-wide dialogue and debate about relevant strategic issues and uncertainties (Abernethy and Brownell, 1999; Abernethy and Lillis, 1995) expands the organization's information processing capacity (Henri, 2006b) and 'build[s] internal pressure to break out of narrow search routines, stimulate opportunity-seeking, and encourage the emergence of new strategic 
initiatives' (Simons, 1995: 93; Bisbe and Otley, 2004; Bruining, Bonnet, and Wright, 2004; Simons, 1994, 1991, 1990; Van de Ven, 1986).

Furthermore, by acting as 'an integrative liaison device that breaks down the functional and hierarchical barriers' in an organization (Abernethy and Brownell, 1999: 192), interactive use leads to the creation of fora for the collective negotiation, rationalisation, legitimisation, and acceptance of strategic decisions (Kober et al., 2007; Simons, 1994, 1990; Dent, 1987). This supports strategic flexibility as it channels potential divergences in strategic decision making, increases the likelihood of common agreement on the need for and best course of action, and maintains crossfunctional coordination (Amason, 1996; DeDreu, 1991; Tjosvold, 1991).

H3: The interactive use of information is positively related to strategic flexibility.

\section{METHOD}

A survey questionnaire was distributed to the Managing Director or General Manager of 540 Australian manufacturing organizations, with more than 100 employees and randomly chosen from the Kompass Australia online database. ${ }^{2}$ Data were collected and analysed in late 2010. The Australian manufacturing industry was chosen for two reasons. First, the Australian manufacturing industry's contribution to the Gross Domestic Product (GDP) was the second highest among the seventeen Australian and New Zealand Standard Industrial Classification (ANZSIC) industries that constitute the national economy, at 9.8 percent in 2007-08 (Australian Bureau of Statistics 2010). Secondly, the Australian manufacturing industry is especially vulnerable to the increasingly frequent, swift, and uncertain environmental change engendered by globalisation, climate change, and rapid technological advancements. Strategic flexibility is especially crucial to organizational effectiveness in such dynamic environments (Volberda, 1998; Hayes and Pisano, 1994). Survey participants were asked to complete the questionnaire with respect to one SBU in their organization and no more than one person in each organization was asked to participate. Managing Directors and General Managers were chosen on the premise that they would possess sufficient knowledge of the strategic capabilities and MCS characteristics of an SBU within their organization and thus be capable of answering the survey questions with respect to that particular SBU.

Dillman's (2007) 'Tailored Design Method' consisting of guidelines concerning the pre-testing, personalization, presentation, and distribution of survey questionnaires was employed. A total of 118 usable questionnaires were returned for a response rate

\footnotetext{
${ }^{2}$ The Kompass Australia online database is a business directory that lists virtually all businesses in Australia, such that a random sample drawn therefrom is likely to be highly representative of the target population.
} 
of 21.9 percent. This compares favourably to other management related studies that reported response rates of 21\% (Gul, 1991), 19.8\% (Clarke and Mia, 1995), 15.5\% (Auzair and Langfield-Smith), 21\% (Kallunki and Silvola), and 14.5\% (Moores and Yuen, 2001). This provided sufficient data for robust structural equation modelling (SEM). The collected data were tested for non-response bias by comparing the data collected from the early respondents (those who responded following the first mailout) with the data collected from the late respondents (those who responded following the second mail-out) across all of the variables of interest (Roberts, 1999). With the exception of the interactive use variable, the results of these tests revealed no significant differences for any of the variables, such that the problems of non-response bias do not likely arise in relation to the data collected in this study.

\section{MEASUREMENT OF VARIABLES}

\section{Information Characteristics}

To measure the scope, timeliness, aggregation, and integration of information, we used a modified version of an existing, validated instrument developed by Chenhall and Morris (1986). To measure the scope of information, respondents were asked to indicate, on a 5-point Likert-type scale with anchors of 'not at all' and 'to a great extent,' the extent to which the business unit's information system provided futureoriented, external, and non-financial information. However, to improve the reliability of the measure above Nunally's (1978) acceptable 0.7 threshold, the overall degree of scope was measured as the combined score for the first two items shown in the Appendix (ranging from 2 to 10), with higher (lower) scores representing broader (narrower) scope.

To measure the timeliness of information, respondents were asked to indicate, on a 5-point Likert-type scale with anchors of 'not at all' and 'to a great extent,' the extent to which the business unit's information system provided reports frequently on a systematic, regular basis; information was delivered immediately upon request; and information was provided automatically upon its input into the information system or as soon as processing was completed. The overall timeliness of information was measured as the combined score for the three items shown in the Appendix (ranging from 3 to 15), with higher (lower) scores representing higher (lower) degrees of timeliness.

To measure the aggregation of information, respondents were asked to indicate, on a 5-point Likert-type scale with anchors of 'not at all' and 'to a great extent,' the extent to which the business unit's information system provided information for multiple time periods (daily, weekly, monthly, etc.); on the effect of different 
departments' activities on the business unit's performance; and in formats suitable for input into decision models (e.g., discounted cash flow analyses, incremental $/$ marginal analyses, 'what-if' analyses). The overall aggregation of information was measured as the combined score for the three items shown in the Appendix (ranging from 3 to 15), with higher (lower) scores representing higher (lower) degrees of aggregation.

To measure the integration of information, respondents were asked to indicate, on a 5-point Likert-type scale with anchors of 'not at all' and 'to a great extent,' the extent to which the business unit's information system provided precise targets for each activity performed within all departments in the business unit, and provided information about the impact of SBU level decisions on the performance of those respective departments as well as the impact on the relevant business unit of other business unit managers' decisions. The overall integration of information was measured as the combined score for the three items shown in the Appendix (ranging from 3 to 15), with higher (lower) scores representing higher (lower) degrees of integration.

\section{Interactive Use of Information}

An adapted version of Henri's (2006b) instrument was used to measure the interactive use of information with respondents asked to indicate, on a 5-point Likerttype scale with anchors of 'not at all' and 'to a great extent,' the extent to which the business unit's management used performance measures to encourage continual challenge and debate of underlying data, assumptions, and action plans; continual dialogue between superiors, subordinates, and peers; achievement of the business unit's objectives; a focus on common issues; and a focus on critical success factors. The overall interactive use of information was measured as the combined score for the five items shown in the Appendix (ranging from 5 to 25), with higher (lower) scores representing higher (lower) degrees of interactive use.

\section{Strategic Flexibility}

Strategic flexibility was measured using a modified version of the Celuch, Murphy, and Callaway (2007) instrument. Respondents were asked to indicate, on a 5point Likert-type scale with anchors of 'not at all' and 'to a great extent,' the extent to which the business unit had the capability to respond to resource reallocation requirements; emerging market opportunities; emerging market threats; changing environmental conditions; changing technology needs; and the need to modify business partnerships (form/dissolve alliances, ventures, etc.). To improve the reliability of the measure, the overall degree of strategic flexibility was measured as 
the combined score for the first three items shown in the Appendix (ranging from 3 to 15), with higher (lower) scores representing higher (lower) degrees of strategic flexibility.

\section{Strategic Change}

Strategic change was measured by asking respondents to indicate, on a 5-point Likert-type scale with anchors of 'not at all' and 'to a great extent,' the extent to which the business unit had undergone change during the past two years with respect to a closed list of thirteen areas of strategic and organizational change (see the Appendix). These areas correspond to the strategic decisions regarding various subject matters identified in the literature (Gimbert, Bisbe, and Mendoza, 2010; Dean and Sharfman, 1996; Cray et al., 1988; Prahalad and Doz, 1987; Schilit, 1987) and relate to changes to both strategy and the organization.

Factor analysis of the measure revealed that 12 of the 13 items loaded onto four dimensions (see Table 1). The first dimension was labelled 'operational change,' the second dimension was labelled 'product/service pricing and quality change' (hereafter 'product change'), the third dimension was labelled 'structural and directional change,' and the fourth dimension was labelled 'marketing change.' The score for each of the four dimensions was initially measured as the combined score for the items loading thereon, with higher (lower) scores representing higher (lower) degrees of change with respect to each dimension.

\section{Descriptive Statistics}

\section{RESULTS}

Table 2 provides the descriptive statistics for the variables in this study. While the Cronbach (1951) alpha coefficients exceed the acceptability threshold of 0.40 (Mital et al., 2008; Sproles and Kendall, 1986), ${ }^{3}$ the scores for the strategic change variables were less than Nunnally's (1978) 0.7 threshold, although it was just under for the recalculated two-item measure of operational strategic change (see Appendix). Given there were also problems in respect to the composite reliability and AVE scores for the other strategic change measures, the SEM analysis focused solely on operational strategic change. Similarly, aggregation was removed from the initial model due to concerns over the Cronbach alpha and composite reliability of this variable.

\footnotetext{
${ }^{3} 0.60-0.70$ is another commonly accepted threshold (Hair et al., 1998; Nunnally, 1978), which the measures in this study exceed or at least approach.
} 
An analysis of the mean scores in Table 2 indicates that information systems tend to provide information which is moderate in terms of scope and integration and which is relatively more timely and aggregated, information tends to be used in an interactive manner, organizations tend to be strategically flexible, and organizations tend to engage in moderate levels of strategic change.

Table 2 Descriptive Statistics Regarding All The Independent and Dependent

\begin{tabular}{|c|c|c|c|c|c|c|}
\hline \multicolumn{7}{|c|}{ Variables } \\
\hline Variables & $\mathrm{n}$ & Mean & $\begin{array}{l}\text { Standard } \\
\text { deviation }\end{array}$ & $\begin{array}{l}\text { Minimum: } \\
\text { actual } \\
\text { (theoretical) }\end{array}$ & $\begin{array}{l}\text { Maximum: } \\
\text { actual } \\
\text { (theoretical) }\end{array}$ & $\begin{array}{l}\text { Cronbach } \\
\text { alpha }\end{array}$ \\
\hline Scope & 117 & 9.05 & 2.34 & $3(3)$ & $14(15)$ & 0.694 \\
\hline Timeliness & 116 & 10.03 & 2.18 & $4(3)$ & $14(15)$ & 0.733 \\
\hline Aggregation & 117 & 10.53 & 2.27 & $4(3)$ & $15(15)$ & 0.646 \\
\hline Integration & 114 & 9.16 & 2.63 & $3(3)$ & $15(15)$ & 0.807 \\
\hline Interactive use & 115 & 18.63 & 3.36 & $6(5)$ & $25(25)$ & 0.835 \\
\hline Strategic flexibility & 115 & 21.03 & 3.77 & $7(6)$ & $30(30)$ & 0.764 \\
\hline \multicolumn{7}{|l|}{ Strategic change } \\
\hline Operational change & 119 & 14.55 & 3.86 & $5(5)$ & $25(25)$ & 0.699 \\
\hline Product change & 119 & 6.60 & 1.57 & $2(2)$ & $10(10)$ & 0.554 \\
\hline Structural change $^{*}$ & 117 & 7.22 & 1.87 & $2(2)$ & $10(10)$ & 0.624 \\
\hline Marketing change & 119 & 8.71 & 2.60 & $3(3)$ & $15(15)$ & 0.594 \\
\hline
\end{tabular}

*'Structural change' refers to the structural and directional dimension of strategic change

\section{Structural Equation Modelling}

Structural equation modelling was used to estimate the base model illustrated in Figure $1 .{ }^{4}$ Our approach was based on a variation of the SEM approach suggested by

Anderson and Gerbing (1988) and employed in the accounting literature (Grafton et al., 2010; Abernethy and Lillis, 2001), which allows alternative nested models to be tested against the base theoretical model in an attempt to produce a parsimonious model which better fits the empirical data. We first estimate the least constrained structural model, Model 1, in which all parameters (i.e., unidirectional paths) are estimated. ${ }^{5}$ We then estimate a series of nested models by sequentially constraining the least significant path coefficient until all remaining paths in the nested model were

\footnotetext{
${ }^{4}$ All structural equation models estimated in this study consisted of both a structural model (which related the latent variables to each other) and a measurement model (which related the latent variables to the observed variables). This permitted the explicit modeling of measurement error and the performance of confirmatory factor analysis, the results of which were consistent with the Cronbach alpha coefficients reported in Table 2. Aggregation was removed from this model due to concerns over the reliability of this variable.

${ }^{5} \mathrm{~A}$ path is constrained when it is set to 0 in the model, and its parameters are not estimated. A path is unconstrained when it is not set to 0 and its parameters are estimated.
} 
significant and the overall model fit the empirical data satisfactorily. Differences in the goodness-of-fit measures relating to each model were observed to ensure that the model had not been overly trimmed or that the relatively parsimonious model was a better fit. This process produced Model 2.

\section{Model 1: The Full SEM Model}

The results of Model 1 are presented in Table 3. Our analysis indicated that our sample of 118 observations was sufficiently large to permit a robust estimation of Model 1. ${ }^{6}$ Seven measures were used to assess the goodness-of-fit: the minimum sample discrepancy divided by the degrees of freedom (CMIN/DF), ${ }^{7}$ the Root Mean Square Error of Approximation (RMSEA), ${ }^{8}$ the Normed Fit Index (NFI), ${ }^{9}$ the Nonnormed Fit Index (NNFI), ${ }^{9}$ the Goodness of Fit Index (GFI), ${ }^{9}$ the Comparative Fit Index (CFI), ${ }^{10}$ and the adjusted goodness of fit index (AGFI). ${ }^{11}$ While the CMIN/DF value of 3.293 for Model 1 was satisfactory, it could be better, while the NNFI value of 0.781 is not acceptable.

Table 3 shows the standardized regression coefficients and corresponding $\mathrm{p}$ values for the associations of interest (or paths) in Model 1. These statistics showed that the timeliness of information $((=0.202 ; \mathrm{p}=0.04)$ and the interactive use of information $((=0.158 ; \mathrm{p}=0.02)$ were associated with strategic flexibility at the 5 percent significance level. Furthermore, strategic flexibility was associated with operational change $((=0.507 ; \mathrm{p}=0.00)$ at the 1 percent significance level.

Table 3 Standardized Regression Coefficients and P-values for Model 1 and Model 2

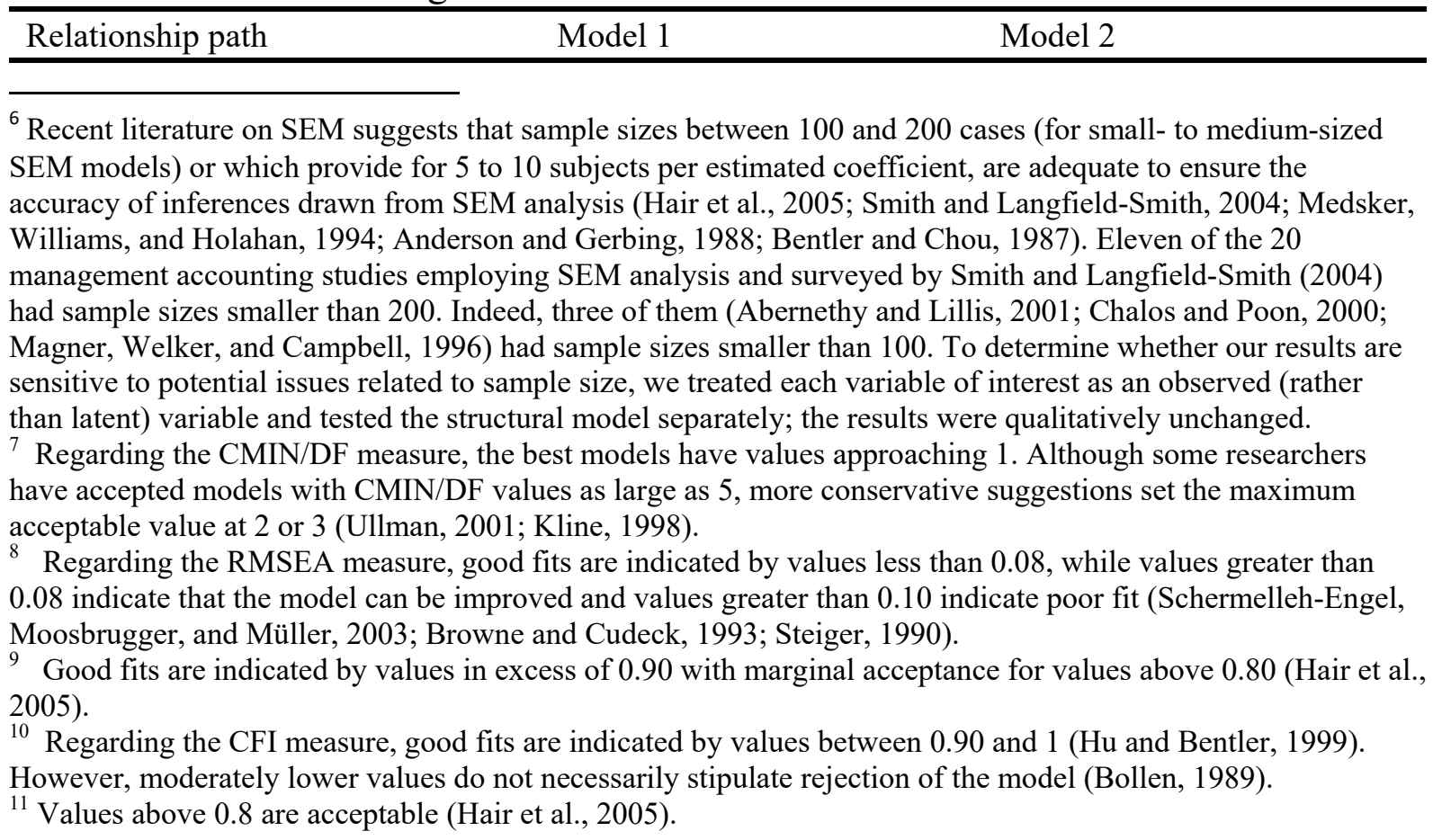




\begin{tabular}{|c|c|c|c|c|}
\hline & Coefficient & Significance & Coefficient & Significance \\
\hline Scope $\rightarrow$ Flexibility ${ }^{\#}$ & 0.106 & 0.34 & $\mathrm{~N} / \mathrm{A}$ & $\mathrm{N} / \mathrm{A}$ \\
\hline Timeliness $\rightarrow$ Flexibility & 0.243 & ${ }^{*} 0.04$ & 0.269 & ${ }^{*} 0.03$ \\
\hline Aggregation $\rightarrow$ Flexibility & 0.161 & 0.18 & $\mathrm{~N} / \mathrm{A}$ & $\mathrm{N} / \mathrm{A}$ \\
\hline Integration $\rightarrow$ Flexibility & -0.104 & 0.16 & N/A & $\mathrm{N} / \mathrm{A}$ \\
\hline Interactive use $\rightarrow$ Flexibility & 0.381 & ${ }^{*} 0.02$ & 0.394 & ${ }^{* *} 0.00$ \\
\hline Flexibility $\rightarrow$ Operational change & 0.630 & ${ }^{* *} 0.00$ & 0.577 & ${ }^{* *} 0.00$ \\
\hline Flexibility $\rightarrow$ Product change & 0.333 & ${ }^{*} 0.02$ & $\mathrm{~N} / \mathrm{A}$ & N/A \\
\hline Flexibility $\rightarrow$ Structural change ${ }^{\dagger}$ & 0.249 & ${ }^{*} 0.02$ & $\mathrm{~N} / \mathrm{A}$ & N/A \\
\hline Flexibility $\rightarrow$ Marketing change & 0.689 & ${ }^{* *} 0.00$ & 0.657 & ${ }^{* *} 0.00$ \\
\hline
\end{tabular}

"Significant at the $5 \%$ significance level

*** Significant at the $1 \%$ significance level

\#'Flexibility' refers to strategic flexibility

'‘Structural change' refers to the structural and directional dimension of strategic change

\section{Model 2: The Reduced SEM Model}

Model 2, the reduced SEM model, resulted from the sequential deletion of statistically insignificant associations of interest in Model 1 (from most insignificant to least insignificant) until all those that remained were significant and the overall model fit the data satisfactorily. ${ }^{12}$ This process substantially improved the fit of the resultant model: the CMIN/DF decreased from 3.293 to 2.397, the NNFI increased from 0.781 to 0.867 , the CFI increased from 0.942 to 0.947 , and the AGFI increased from 0.820 to 0.868 . Overall, the seven goodness-of-fit measures indicate that the goodness-of-fit assumption was appropriate.

The standardized regression coefficients and corresponding p-values for Model 2 are presented in Table 3. The statistics for Model 2 showed that the timeliness of information $((=0.243 ; \mathrm{p}=0.00)$ and the interactive use of information $((=0.183 ; \mathrm{p}=$ $0.00)$ were still associated with strategic flexibility at the 1 percent significance level. These findings provide support for $\mathrm{H} 2 \mathrm{~b}$ and $\mathrm{H} 3$. Strategic flexibility was still associated with operational strategic change $(\beta=0.507 ; p=0.00)$.

The mediating role of strategic flexibility was examined by reference to the approach suggested by James and Brett (1984) and recently adopted by Nadkarni and Herrmann (2010) in their study of strategic flexibility. According to this approach, mediation exists in cases in which the paths between the independent variable and the mediator and between the mediator and the dependent variable are both significant

\footnotetext{
${ }^{12}$ The same variables and associations of interest remained in the model when the sequence was performed in reverse (i.e., where variables and paths were sequentially added to the model, with insignificant paths removed at each step). Also note that the same results were obtained using different combinations of the items used to measure strategic flexibility and operational strategic change. Hence, while the number of items used for these measures was reduced to improve the reliability of the measures, the same findings were observed when all items were used.
} 
and the overall model shows acceptable goodness-of-fit (Nadkarni and Herrmann, 2010; James, Mulaik, and James, 2006). ${ }^{13}$ This is evidently the case in respect of Model 2, such that strategic flexibility can be said to mediate the relationships between timeliness and the two dimensions of strategic change and between interactive use and the two dimensions of strategic change. ${ }^{14}$

\section{DISCUSSION AND CONCLUSION}

\section{Discussion of The Results and Their Implications}

This study empirically examined the associations between specific MCS characteristics and strategic flexibility and between strategic flexibility and strategic change. Additionally, the study explored whether and in what instances strategic flexibility mediates the association between specific MCS characteristics and strategic change. In so doing, the study has sought to develop a more comprehensive theory of strategic management in dynamic environments based on empirical insight into the role of strategic flexibility as a product of MCS characteristics, an enabler of strategic change, and a mediating variable accounting for the relationships between MCS characteristics and strategic change.

The study's results indicated that two MCS characteristics (the timeliness and interactive use of information) are significantly related to strategic flexibility, that strategic flexibility is significantly related to the operational strategic change dimension, and that strategic flexibility mediates the relationships between these particular MCS characteristics and operational strategic change.

The finding that MCS characteristics facilitate strategic flexibility provides empirical evidence in support of the literature (Gond et al., 2012; Shimizu and Hitt, 2004). The significant, positive association between the timeliness of information and strategic flexibility indicates that organizations tend to be more strategically flexible when the information system provides more timely information. This suggests that organizations seeking to develop strategic flexibility ought to focus on information

\footnotetext{
${ }^{13}$ This approach differs from the alternative Baron and Kenny (1986) approach in a number of ways. In particular, the adopted approach does not require as a condition for mediation either a significant direct relationship between the independent variable (the MCS characteristic) and the dependent variable (the dimensions of strategic change) or a significant decrease in the coefficient of the relationship between the independent variable and the dependent variable upon the mediator's inclusion in the model (James et al., 2006; Shrout and Bolger, 2002).

${ }^{14}$ Further evidence of mediation is indicated by the superior goodness-of-fit of Model 2 (a fully mediated model) relative to that of an equivalent partially mediated model (which includes paths from each MCS characteristic to both strategic flexibility and the dimensions of strategic change) and an equivalent fully mediated model (which only includes paths from each MCS characteristic directly to the dimensions of strategic change). This also indicates complete mediation (i.e., strategic flexibility accounts fully for the relationships between these MCS characteristics and operational strategic change).
} 
that is timely in terms of the frequency and speed with which it is reported to decision makers (Bouwens and Abernethy, 2000). This could entail, for instance, investment in systems that facilitate the provision of information as soon as possible following the events to which it relates; the generation of reports on a frequent, systematic, and regular basis; and the delivery of information immediately upon request or upon its input into the information system. The implication is a plausible one since the timely identification of environmental change is, by definition, central to strategic flexibility.

The significant, positive association between the interactive use of information and strategic flexibility indicates that organizations tend to be more strategically flexible when information is used more interactively. This finding provides empirical evidence in support of case study evidence which has purported this association (Kober et al., 2007; Archer and Otley, 1991; Roberts, 1990). Hence, it is suggested that organizations seeking to develop strategic flexibility ought to, for instance, facilitate the increased and recurrent flow of information throughout the organization and encourage the personal involvement of managers at all levels in the decisionmaking activities of subordinates. This implication is a plausible one, considering the recognition and qualitative evidence of the interactive use of information as a tool for strategic renewal, which stimulates opportunity seeking and facilitates the emergence, acceptance, and coordinated execution of strategic initiatives (Simons, 1995).

The significant, positive association between strategic flexibility and operational strategic change indicates that strategically flexible organizations are more likely to engage in operational change (e.g., concerning technology adoption, business partnerships, distribution channels, and the range of products/services). The implication is a plausible one because the actual realisation of strategic flexibility as a capability to adapt to environmental change would necessarily entail strategic change. Hence, the suggestion is that organizations seeking sustainable alignment with dynamic environments ought to focus on the development of strategic flexibility (by providing for more timely information and the interactive use of information).

The significant, positive, and simultaneously existing associations between the timeliness and interactive use of information and strategic flexibility and between strategic flexibility and operational strategic change indicate that strategic flexibility mediates the relationships between those MCS characteristics and operational strategic change: the MCS characteristics influence strategic flexibility, which separately and subsequently influences the dimensions of strategic change (Baron and Kenny, 1986). Such findings support the claims of Henri (2006b) that the link between MCS and strategic change exists at the capabilities level. Therefore, the focus in the extant literature on strategic change as a direct product of MCS characteristics 
has been misplaced with respect for some variables, including the interactive use variable, as studied in Naranjo-Gil and Hartmann (2007) and Abernethy and Brownell (1999).

\section{Contributions of The Study}

Prior to this study, empirical research had largely neglected or otherwise taken for granted the relevance of strategic flexibility to the MCS-strategic change relationship. Meanwhile, non-empirical research had been largely speculative and provided an unsatisfactory basis upon which to distinguish the actual and potential relevance of strategic flexibility. In that context, and through the empirical elucidation of significant associations between these variables, this study sought insight into the role of strategic flexibility as a product of MCS characteristics, an enabler of strategic change, and a mediating variable accounting for the relationships between MCS characteristics and strategic change. The incorporation of strategic capabilities as mediators in the MCS-strategy relationship is an important emerging development in the literature (Grafton et al., 2010; Henri, 2006). The identification of such intervening variables is important because, as Epstein (2002) argues, effective management demands a close understanding of value drivers (in this case, strategic change and adaptation) and the specific causal relations critical thereto.

The study's findings offer a more comprehensive theory of strategic management in dynamic environments, which contributes to the MCS-strategy literature and informs the practice of organizational management with reference to the resourcebased view of the firm. In particular, the findings indicate to researchers in the MCSstrategy field that, although some MCS characteristics might lead directly to strategic change, greater attention should be paid to the role of strategic flexibility as a product of MCS characteristics, an enabler of strategic change, and a mediator in the relationships between certain MCS characteristics and dimensions of strategic change. The findings also indicate to managers what is needed to achieve organizational effectiveness in dynamic environments; namely, the development and management of organizational resources (i.e., MCS characteristics) and thereby strategic capability (i.e., strategic flexibility), which is critical to the sustenance of long-term competitive advantage by virtue of its facilitation of shorter-term (re)alignments of organizational strengths and weaknesses with environmental opportunities and threats (i.e., strategic change).

\section{Limitations of The Study and Suggestions for Future Research}


This study is subject to a number of limitations. First, employment of the mail survey method entails the usual set of limitations, including the potential for endogeneity ${ }^{15}$ and common method bias. ${ }^{16}$ Furthermore, the method does not permit the elimination of rival explanations or, therefore, the establishment of cause-andeffect relations between variables of interest; at best, such is inferred from the consistency of significant associations with theories suggesting causation (Singleton and Straits, 2010). Future studies could combine a survey with longitudinal field research, including interviews with not only those top executives completing the questionnaire, but also with lower-level managers in the organization.

Secondly, given the low convergent validity in respect to strategic flexibility and the strategic change variables, future studies may confirm the observed associations using improved measures. Thirdly, the limitation of the study's sample frame to organizations within the Australian manufacturing industry can correspondingly limit the generalizability of the study's findings to organizations within other industries, including manufacturing industries outside Australia. The strategy literature suggests that drivers of organizational change are different for firms in dynamic environments and stable environments (Nadkarni and Narayanan, 2007; Bogner and Barr, 2000; Eisenhardt and Martin, 2000), and the MCS literature suggests that MCS characteristics that are effective in dynamic environments (e.g., the interactive use of information) are less so in stable environments. Accordingly, replication of this study in subgroupings of the manufacturing industry to capture companies in stable environments as well as those in dynamic environments could be undertaken. Further replication studies could be considered in other industries (either manufacturing industries in other countries or non-manufacturing industries), and control of the environmental dynamism variable would permit an assessment of the generalizability of the study's findings.

Other opportunities for future research emerge from this study and its findings. In particular, the MCS characteristics examined in this study are merely few of many

\footnotetext{
${ }^{15}$ Although it has been suggested that strategy may influence a MCS just as a MCS may influence strategy (Simons, 1994), such that strategic flexibility may influence MCS characteristics and be influenced by strategic change, the literature and the resource-based view of the firm (Grant, 1991) provide sufficient theoretical support for the structural model adopted in this study and for the interpretation of those MCS-strategy associations identified by this study. This should alleviate any concerns about possible endogeneity.

${ }^{16}$ Common method bias might arise in this study due to the repeated use of relatively short, Likert-type scales with the same or similar anchor points and explain some of the covariation observed among the variables. Harman's single-factor test, a diagnostic tool allowing for an assessment of the extent to which common-method bias may be a problem, was carried out (Podsakoff et al., 2003). The outcome of that test (which involved loading all items measuring the variables of interest into an exploratory factor analysis in order to determine whether any one general factor accounts for the majority of the covariance among the measures) did not identify any such bias. This, however, is no guarantee that there is no common method bias.
} 
possible antecedents to strategic flexibility. It is thus hardly conceivable that any single study or model would explain an especially large proportion of the variation in strategic flexibility. Future research should consider examining other organizational characteristics (whether MCS-related or otherwise) either separately or in addition to those examined in this study. The same suggestion applies to the antecedents to strategic change.

\section{REFERENCE}

Aaker, D. A. \& Mascarenhas, B. (1984). The need for strategic flexibility. Journal of Business Strategy, 5(2), 74-82. http://dx.doi.org/10.1108/eb039060

Abbott, A. \& Banerji, K. (2003). Strategic flexibility and firm performance: the case of US based transnational corporations. Global Journal of Flexible Systems Management, 4(1-2), 1-8.

Abernethy, M. A. \& Brownell, P. (1999). The role of budgets in organizations facing strategic change: an exploratory study. Accounting, Organizations and Society, 24(3), 189-204. http://dx.doi.org/10.1016/S0361-3682(98)00059-2

Abernethy, M. A. \& Lillis, A. M. (1995). The impact of manufacturing flexibility on management control system design. Accounting, Organizations and Society, 20(4), 241-258. http://dx.doi.org/10.1016/0361-3682(94)E0014-L

Ackoff, R. L. (1967). Management misinformation systems. Management Science, 14(4), 147-156. http://dx.doi.org/10.1287/mnsc.14.4.B147

Akhtar, M. \& Mittail, R.K. (2014).Strategic flexibility information system flexibility and enterprise performance management. Organizational Flexibility and Competitiveness, Flexible Systems Management, 41-51.Nandakumar, M.K, Jharkharia, S. \& Nair, A. (Eds)

Amason, A. C. (1996). Distinguishing the effects of functional and dysfunctional conflict on strategic decision making: resolving a paradox for top management teams. Academy of Management Journal, 39(1), 123-148. http://dx.doi.org/10.2307/256633

Anderson, J. \& Gerbing, D. (1988). Structural equation modeling in practice: a review and recommended two step approach. Psychological Bulletin, 103(3), 411-423. http://dx.doi.org/10.1037/0033-2909.103.3.411

Anthony, R. H. \& Govindarajan, V. (2007). Management Control Systems, $12^{\text {th }}$ Edition, McGraw-Hill Irwin, New York.

Archer, S. \& Otley, D. T. (1991). Strategy, structure, planning and control systems and performance evaluation - Rumenco Ltd. Management Accounting Research, 2(4), 263-303. http://dx.doi.org/10.1016/S1044-5005(91)70038-3 
Arief, M., Thoyib, A, Sudiro, A. \& Rohman, F. (2013). The effect of entrepreneurial orientation on the firm performance through strategic flexibility: a study on the SMEs cluster in Malang. Journal of Management Research, 5(3), 44-62.

Atkinson, A. A., Banker, R. D., Kaplan, R. S. \& Young, M. (1997). Management Accounting, Prentice Hall, Upper Saddle River.

Australian Bureau of Statistics, (2010). Year Book Australia 2009-10, Catalogue No. 1301.0. Australian Government Publishing Service, Canberra.

Auzair, S. M. \& Langfield-Smith, K. (2005). The effect of service process type, business strategy an life cycle stage on bureaucratic MCS in service organisations. Management Accounting Research, 16(4), 399-421. http://dx.doi.org/10.1016/j.mar.2005.04.003

Baron, R. M. \& Kenny, D. A. (1986). The moderator-mediator variable distinction in social psychological research: conceptual, strategic and statistical considerations. Journal of Personality and Social Psychology, 51(6), 1173-1182. http://dx.doi.org/10.1037/0022-3514.51.6.1173

Baum, J. R. \& Wally, S. (2003). Strategic decision speed and firm performance. Strategic Management Journal, 24(11), 1107-1129.

Bednar, M.K, Bolvie, S. \& Prince, N. R. (2012). Burr under the saddle: how media coverage influences strategic change. Organization Science, 24(3), 910-925.

Bentler, P. M. \& Chou, C. P. (1987). Practical issues in structural modelling. Sociological Methods and Research, 16(1), 78-117.

Bettis, R. A. \& Hitt, M. A. (1995). The new competitive landscape. Strategic Management Journal, $16(1)$ 7-19. http://dx.doi.org/10.1177/0049124187016001004

Bhimani, A. \& Langfield-Smith, K. (2007). Structure, formality and the importance of financial and non-financial information in strategy development and implementation. Management Accounting Research, 18(1), 3-31. http://dx.doi.org/10.1016/j.mar.2006.06.005

Bisbe, J. \& Otley, D. (2004). The effects of the interactive use of management control systems on product innovation. Accounting, Organizations and Society, 29(8), 709-737. http://dx.doi.org/10.1016/j.aos.2003.10.010

Bogner, W. C. \& Barr, P. S. (2000). Making sense of hyper competitive environments: A cognitive explanation for the persistence of high velocity competition. Organization Science, 11(2), 212-216. http://dx.doi.org/10.1287/orsc.11.2.212.12511 Bollen, K. A. (1989). Structural Equations with Latent Variables, Wiley, New York. 
Bouwens, J. \& Abernethy, M. A. (2000). The consequences of customization on management accounting system design. Accounting, Organizations and Society, 25(3), 221-241. http://dx.doi.org/10.1016/S0361-3682(99)00043-4

Browne, M. W. \& Cudeck, R. (1993). Alternative ways of assessing model fit. In Testing Structural Equation Models, Bollen, K. A. and J. S. Long, (Eds.), Sage, Newsbury Park.

Bruining, H., Bonnet, M. \& Wright, M. (2004). Management control systems and strategy change in buyouts. Management Accounting Research, 15(2), 155-177. http://dx.doi.org/10.1016/j.mar.2004.03.003

Buckley, P. J. \& Casson, M. C. (1998). Models of the multinational enterprise. Journal of International Business Studies, 29(1), 21-44.

Burns, T. \& Stalker, G. M. (1961). The Management of Innovation. Tavistock Publications, London.

Byrd, T. A. (2001). Information technology: core competencies, and sustained competitive advantage. Information Resources Management Journal, 14(2), 2736.

Celuch, K., Murphy, G. B. \& Callaway, S. K. (2007). More bang for your buck: small firms and the importance of aligned information technology capabilities and strategic flexibility. Journal of High Technology Management Research, 17(2), 187-197. http://dx.doi.org/10.1016/j.hitech.2006.11.006

Chalos, P. \& Poon, M. C. (2000). Participation and performance in capital budgeting teams. Behavioral Research in Accounting, 12, 199-229.

Chenhall, R.H, Kallunki, J.P. \& Silvola, H. (2011). Exploring the relationships between strategy, innovation, and management control systems: the roles of social networking, organic innovative culture and formal controls. Journal of Management Accounting Research, 23(1), 99-128. http://dx.doi.org/10.2308/jmar-10069

Chenhall, R. H. \& Langfield-Smith, K. (2003). Performance measurement and reward systems, trust and strategic change. Journal of Management Accounting Research, 15(1), 117-143. http://dx.doi.org/10.2308/jmar.2003.15.1.117

Chenhall, R. H. \& Langfield-Smith, K. (1998). The relationship between strategic priorities, management techniques and management accounting: an empirical investigation using a systems approach. Accounting, Organizations and Society, 23(3), 243-264. http://dx.doi.org/10.1016/S0361-3682(97)00024-X

Chenhall, R. H. \& Morris, D. (1986). The impact of structure, environment and interdependence on the perceived usefulness of management accounting systems. Accounting Review, 61(1), 16-35. http://www.jstor.org/stable/247520 
Cingoz, A., Asuman, A. \& Dogan, A. K. (2013). Strategic flexibility, environmental dynamics and innovative performance: an empirical study. The Proceedings of $9^{\text {th }} \quad$ Iternational Strategic Management Conference, 99,582-589. http://dx.doi.org/10.1016/j.sbspro.2013.10.528

Clarke, B. \& Mia, L. (1995). Activity-based costing system: use and application in Australia, Monash University Syme School of Accounting, Research Paper in Applied Accounting and Finance, Discussion Paper 8, Series II.

Combe, I. A. \& Greenley, G. E. (2004). Capabilities for strategic flexibility: a cognitive content framework. European Journal of Marketing, 38(11-12), 14561480.

Cray, D., Mallory, G.R., Butler, R. J., Hickson, D. J. \& Wilson, D. C. (1988). Sporadic, fluid and constricted processes: three types of strategic decision making in organizations. Journal of Management Studies, 25(1), 13-39. http://dx.doi.org/10.1111/j.1467-6486.1988.tb00020.x

Cronbach, L. J. (1951). Coefficient alpha and the internal structure of tests. Psychometrika, 16(3), 297-334.

Das, T. \& Elango, B. (1995). Managing strategic flexibility: key to effective performance. Journal of General Management, 20(3), 60-73.

Davila, T. (2005). The promise of management control systems for innovation and strategic change. In Controlling Strategy: Management, Accounting, and Performance Measurement, Chapman C. S. (Ed.), Oxford University Press, New York.

Dean, J. W. \& Sharfman, M. P. (1996). Does decision process matter? A study of strategic decision-making effectiveness. Academy of Management Journal, 39(2), 368-396. http://dx.doi.org/10.2307/256784

DeDreu, C. K. (1991). Productive conflict: the importance of conflict management and conflict issue, In Using Conflict in Organizations, DeDreu, C. K. \& Van de Vliert, E. (Eds.), Sage Publications, London.

Dent, J. F. (1987). Tensions in the design of formal control systems: a field study in a computer company. In Accounting and Management: Field Study Perspectives, Bruns, W. J. \& Kaplan, R. S. (Eds.), Harvard Business School Press, Boston.

Dillman, D. A. (2007). Mail and Internet Surveys: The Tailored Design Method, $2^{\text {nd }}$ edition, Wiley, New York.

Drnevich, P. L. \& Kriauciunas, A. P. (2011). Clarifying the conditions and limits of the contributions of ordinary and dynamic capabilities to relative firm performance. Strategic Management Journal, 32(3), 254-279. 
Dwyer, L.M, Cvelbar.L.K, Edwards, D. \& Mihalic, T.A. (2013). Tourism firms' strategic flexibility: the case of Slovenia. International Journal of Tourism Research, 16(4), 377-387

Eisenhardt, K. M. \& Martin, J. A. (2000). Dynamic capabilities: What are they? Strategic Management Journal, 21(10-11), 1105-1121. http://www.jstor.org/stable/3094429

Epstein, M. J. (2002). Measuring the payoffs of corporate actions: the use of financial and non-financial indicators. In Performance Measurement and Management Control: A Compendium of Research, Epstein, M. J. \& Manzoni, J. F. (Eds.), Elsevier Science, Oxford.

Galbraith, J. (1973). Designing Complex Organizations, Addison-Wesley, Reading.

Galbraith, J. (1977). Organization Design, Addison-Wesley, Reading.

Garud, R. \& Kotha, S. (1994). Using the brain as a metaphor to model flexible production systems. Academy of Management Review, 19(4), 671-698. http://dx.doi.org/10.5465/AMR.1994.9412190215

Gerdin, J. (2005). The impact of departmental interdependencies and management accounting system use on subunit performance. European Accounting Review, 14(2), 297-328.

Gimbert, X., Bisbe, J. \& Mendoza, X. (2010). The role of performance measurement systems in strategy formulation processes. Long Range Planning, 43(4), 477-497. http://dx.doi.org/10.1016/j.lrp.2010.01.001

Goldhar, J. D. \& Lei, D. (1995). Variety is free: manufacturing in the twenty-first century. Academy of Management Executive, 9(4), 73-86. http://dx.doi.org/10.5465/AME.1995.9512032197

Gond, J.P., Grubnic, S., Herzig,C. \&Moon, J. (2012). Configuring management control systems: theorizing the integration of strategy and sustainability. Management Accounting Research, 205-223. http://dx.doi.org/10.1016/j.mar.2012.06.003

Gordon, L. A. \& Miller, D. (1976). A contingency framework for the design of accounting information systems. Accounting, Organizations and Society, 1(1), 59-69. http://dx.doi.org/10.1016/0361-3682(76)90007-6

Gordon, L. A. \& Narayanan, V. K. (1984). Management accounting systems, perceived environmental uncertainty and organization structure: an empirical analysis. Accounting, Organizations and Society, 9(1), 33-47. http://dx.doi.org/10.1016/0361-3682(84)90028-X

Grafton, J., Lillis, A. M. \& Widener, S. K. (2010). The role of performance measurement and evaluation in building organizational capabilities and 
performance. Accounting, Organizations and Society, 35(7), 689-706. http://dx.doi.org/10.1016/j.aos.2010.07.004

Grant, R. M. (1991). The resource-based theory of competitive advantage: Implications for strategy formulation, California Management Review, 33(3), 114-135. http://dx.doi.org/10.2307/41166664

Greiner, L. E. \& Bhambri, A. (1989). New CEO intervention and dynamics of deliberate strategic change. Strategic Management Journal, 10(1), 67-86. http://dx.doi.org/10.1002/smj.4250100707

Grewal, R. \& Tansuhaj, P. (2001). Building organizational capabilities for managing economic crisis: the role of market orientation and strategic flexibility. Journal of Marketing, 65(2), 67-80. http://dx.doi.org/10.1509/jmkg.65.2.67.18259

Gul, F.A. (1991). The effects of management accounting systems and environmental uncertainty on small business managers performance. Accounting and Business Research, 22(85), 57-61. http://dx.doi.org/10.1080/00014788.1991.9729418

Hair, J. E., Black, W. C., Babin, B. J., Anderson, R. E. \& Tatham, R. L. (2005). Multivariate Data Analysis, $6^{\text {th }}$ edition, Prentice-Hall, New Jersey.

Hatch, J. \& Zweig, J. (2001). Strategic flexibility: the key to growth. Ivey Business Journal, 33, 44-47.

Hayes, R. H. \& Pisano, G. P. (1994). Beyond world-class: the new manufacturing strategy. Harvard Business Review, 72(1), 77-86.

Helfat, C. E., Finkelstein, S., Mitchell, W., Peteraf, M. A., Singh, H., Teece, D. J. \& Winter, S. G. (2007). Dynamic Capabilities: Understanding Strategic Change In Organizations, Blackwell Publishing, Oxford.

Henri, J. (2006a). Organizational culture and performance measurement systems. Accounting, Organizations and Society, 31(1), 77-103. http://dx.doi.org/10.1016/j.aos.2004.10.003

Henri, J. (2006b). Management control systems and strategy: a resource-based perspective. Accounting, Organizations and Society, 31(6) 529-558. http://dx.doi.org/10.1016/j.aos.2005.07.001

Herrman, P. \& Nadkarni, S. (2014). Managing strategic change: the duality of CEO personality. Strategic Management Journal, 35(9), 1318-1342. http://dx.doi.org/10.1002/smj.2156

Hitt, M. A., Keats, B. W. \& DeMarie, S. M. (1998). Navigating in the new competitive landscape: building strategic flexibility and competitive advantage in the 21st century. Academy of Management Executive, 12(4), 22-42. http://dx.doi.org/10.5465/AME.1998.1333922 
Hrebiniak, L. G. \& Joyce, W. F. (1985). Organizational adaptation: strategic choice and environmental determinism. Administrative Science Quarterly, 30(3), 336349. http://www.jstor.org/stable/2392666

Hu, L. T. \& Bentler, P. M. (1999). Cutoff criteria for fit indexes in covariance structure analysis: Conventional criteria versus new alternatives. Structural Equation Modeling: A Multidisciplinary Journal, 16(1), 1-55. http://dx.doi.org/10.1080/10705519909540118

Ittner, C. D., Larcker, F. \& Randall, T. (2003). Performance implications of strategic performance measurement in financial services firms. Accounting, Organizations and Society, 28(7-8), 715-741. http://dx.doi.org/10.1016/S0361-3682(03)000333

Jaeger, A. M. \& Baliga, B. R. (1985). Control systems and strategic adaptation: lessons from the Japanese experience. Strategic Management Journal, 6(2), 115 134. http://dx.doi.org/10.1002/smj.4250060203

James, L. R. \& Brett, J. M. (1984). Mediators, moderators, and tests for mediation. Journal of Applied Psychology, 69(2), 307-321. http://dx.doi.org/10.1037/00219010.69.2.307

James, L. R., Mulaik, S. A. \& Brett, J. M. (2006). A tale of two methods. Organizational Research Methods, 9(2), 233-244.

Kandemir, D. \& Acur, N. (2012). Examining proactive strategic decision-making flexibility in new product development. Journal of Product Innovation Management, 29(4), 608-622. http://dx.doi.org/10.1111/j.15405885.2012.00928.x

Kallunki, J. P. \& Silvola, H. (2008). The effect of organizational life cycle stage on the use of activity-based costing. Management Accounting Research, 19(1), 6279. http://dx.doi.org/10.1016/j.mar.2007.08.002

Kaul, M. (1997). The New Public Administration: management innovations in government. Public Administration and Development, 17(1), 13-26.

Kelly, D. \& Amburgey, T. L. (1991). Organizational inertia and momentum: a dynamic model of strategic change. Academy of Management Journal, 34(3), 591-612. http://dx.doi.org/10.2307/256407

Kline, R. B. (1998). Principles and Practice of Structural Equation Modeling, Guilford Press, New York.

Kober, R., Ng, J. \& Paul, B. J. (2007). The interrelationship between management control mechanisms and strategy. Management Accounting Research, 18(4), 425452. http://dx.doi.org/10.1016/j.mar.2007.01.002 
Kotha, S. (1995). Mass customization: implementing the emerging paradigm for competitive advantage. Strategic Management Journal, 16(1), 21-42. http://dx.doi.org/10.1002/smj.4250160916

Lant, T. K. \& Montgomery, D. B. (1987). Learning from strategic success and failure. Journal of Business Research, 15(6), 503-518. http://dx.doi.org/ 10.1016/01482963(87)90035-X

Larcker, D. F. (1981). The perceived importance of selected information characteristics for strategic capital budgeting. Accounting Review, 56(3), 519-528. http://www.jstor.org/stable/246913

Lau, R.S. (1996). Strategic flexibility: A new reality for world-class manufacturing. S.A.M. Advanced Management Journal, 61(2), 11-17.

Lei, D., Hitt, M. A. \& Goldhar, J. D. (1996). Advanced manufacturing technology: organizational design and strategic flexibility. Organization Studies, 17(3), 501517. http://dx.doi.org/10.1177/017084069601700307

Liu, H., Zhang, J. \& Zao, X. (2013). Strategic flexibility and international venturing by emerging market firms; the moderating effects of institutional and relations factors. Journal of International Marketing, 21(2), 79-98. http://dx.doi.org/10.1509/jim.12.0047

MacKay,R.B.\& Chia, R. (2013). Choice, chance, and unintended consequences in strategic change; a process understanding of the rise and fall of Northco Automotive. Academy of Management Journal, 56(1), 208-230.

MacKinnon, W., Grant, G. \& Cray, D. (2008). Enterprise Information Systems and Strategic Flexibility. In Proceedings of the $41^{\text {st }}$ Hawaii International Conference on System Sciences, Honolulu, 1-9. http://dx.doi.org/10.1109/HICSS.2008.149

Magner, N., Welker, R. B. \& Campbell, T. L. (1996). Testing a model of cognitive budgetary participation processes in a latent variable structural equations framework. Accounting and Business Research, 27(1), 41-50. http://dx.doi.org/10.1080/00014788.1996.9729530

Matusik, S. F. \& Hill, C. W. (1998). The utilization of contingent work, knowledge creation, and competitive advantage. Academy of Management Review, 23(4), 680-697. http://dx.doi.org/10.5465/AMR.1998.1255633

Medsker, G. L., Williams, L. J. \& Holahan, P. J. (1994). A review of current practices for evaluating causal models in organizational behaviour and human resources management research. Journal of Management, 20(2), 439-464. http://dx.doi.org/10.1177/014920639402000207

Mia, L. \& Chenhall, R. H. (1994). The usefulness of management accounting systems, functional differentiation and managerial effectiveness. Accounting, 
Organizations and Society, 19(1), 1-13. http://dx.doi.org/10.1016/03613682(94)90010-8

Mintzberg, H. \& McHugh, A. (1985). Strategy formation in an adhocracy. Administrative Science $\quad$ Quarterly, $\quad$ 30(2), 197.http://www.jstor.org/stable/2393104

Mital, A., Desai, A., Subramanian A. \& Mital, A. (2008). Product Development: A Structured Approach to Consumer Product Development, Design and Manufacture, Elsevier, Oxford.

Modell, S. (2004). Performance measurement myths in the public sector: a research note. Financial Accountability and Management, 20(1), 39-55. http://dx.doi.org/10.1111/j.1468-0408.2004.00185.x

Moores, K. \& Yuen, S. (2001). Management accounting systems and organisational configuration: a life-cycle perspective. Accounting and Business Research, 26(45), 351-389. http://dx.doi.org/10.1016/S0361-3682(00)00040-4

Nadkarni, S. \& Herrmann, P. (2010). CEO personality, strategic flexibility, and firm performance: The case of the Indian business process outsourcing industry. Academy of Management Journal, 53(5), 1050-1073. http://dx.doi.org/10.5465/AMJ.2010.54533196

Nadkarni, S. \& Narayanan, V. K. (2007). Strategic schemas, strategic flexibility, and firm performance: The moderating role of industry clockspeed. Strategic Management Journal, 28(3), 243-270. http://dx.doi.org/10.1002/smj.576

Naranjo-Gil, D. \& Hartmann, F. (2007). Management accounting systems, top management team heterogeneity and strategic change. Accounting, Organizations and Society, 32(7-8), 735-756. http://dx.doi.org/10.1016/j.aos.2006.08.003

New Oxford American Dictionary, (2005). $2^{\text {nd }}$ edition, Oxford University Press, New York.

Nunnally, J.C. (1978). Psychometric Theory, McGraw-Hill, New York.

O'Reilly, C. (1983). The use of information in organizational decision making: a model and some propositions. In Research in Organizational Behaviour, Straw, B.M. \& Cummings, L. L. (Eds.), JAI Press, Greenwich.

Podsakoff, P.M., MacKenzie, S. B., Lee, J. \& Podsakoff, N. P. (2003). Common method biases in behavioral research: A critical review of the literature and recommended remedies. Journal of Applied Psychology, 88(5), 879-903. http://dx.doi.org/10.1037/0021-9010.88.5.879

Prahalad, Y. \& Doz, L. (1987). The Multinational Mission: Balancing Local Demands and Global Vision. The Free Press: New York. 
Roberts, E.S. (1999). In defence of the survey method: an illustration from a study of user information satisfaction. Accounting and Finance, 39(1), 53-79. http://dx.doi.org/10.1111/1467-629X.00017

Roberts, J. (1990). Strategy and accounting in a UK conglomerate. Accounting, Organizations and Society, 15(1-2), 107-126.

Roberts, N. \& Stockport, G. J. (2014). Defining strategic flexibility. The Flexible Enterprise, Flexible Systems Management, 37-45. Sushil, S., Stohr, E., \& Springe I. (Eds.)

Sanchez, R. (1995). Strategic flexibility in product competition. Strategic Management Journal, 16(1), 135-159. http://dx.doi.org/10.1002/smj.4250160921

Sanchez, R. (1997a). Managing for an uncertain future: a systems view of strategic organizational change. International Studies of Management and Organization, 27(2), 21-42. http://dx.doi.org/10.1080/00208825.1997.11656706

Sanchez, R. (1997b). Preparing for an uncertain future. International Studies of Management and Organization, 27(2), 71-94.

Schermelleh-Engel, K., Moosbrugger, H. \& Müller, H. (2003). Evaluating the fit of structural equation models: tests of significance and descriptive goodness-of-fit measures. Methods of Psychological Research Online, 8(2), 23-74.

Schilit, W.K. (1987). An examination of the influence of middle-level managers in formulating and implementing strategic decisions. Journal of Management Studies, 24(3), 271-293. http://dx.doi.org/10.1111/j.1467-6486.1987.tb00703.x

Schoen, O. (2012). Business model modularity- a way to gain strategic flexibility. Controlling \&Management Review, 56(2), 73-78. http://dx.doi.org/10.1365/s12176-012-0388-4

Sharfman, M.P. \& Dean, J. W. (1997). Flexibility in strategic decision making: informational and ideological perspectives. Journal of Management Studies, 34(2), 191-217. http://dx.doi.org/10.1111/1467-6486.00048

Shimizu, K. \& Hitt, M. A. (2004). Strategic flexibility: organizational preparedness to reverse ineffective strategic decisions. Academy of Management Executive, 18(4), 44-59. http://dx.doi.org/10.5465/AME.2004.15268683

Shortell, S.M. \& Zajac, E. (1990). Perceptual and archival measures of Miles and Snow's strategic types: a comprehensive assessment of reliability and validity. Academy of Management Journal, 33(4), 817-832. http://dx.doi.org/10.2307/256292 
Shrout, P.E. \& Bolger, N. (2002). Mediation in experimental and nonexperimental studies: New procedures and recommendations. Psychological Methods, 7(4), 422-445. http://dx.doi.org/10.1037/1082-989X.7.4.422

Simons, R. (1987). Accounting control systems and business strategy: an empirical analysis. Accounting, Organizations and Society, 12(4), 357-374. http://dx.doi.org/10.1016/0361-3682(87)90024-9

Simons, R. (1990). The role of management control systems in creating competitive advantage: new perspectives. Accounting, Organizations and Society, 15(1-2), 127-143.

Simons, R. (1991). Strategic orientation and top management attention to control systems. Strategic Management Journal, 12(1), 49-62. http://dx.doi.org/10.1002/smj.4250120105

Simons, R. (1994). How new top managers use control systems as levers of strategic renewal. Strategic Management Journal, 15(3), 169-189. http://dx.doi.org/10.1002/smj.4250150301

Simons, R. (1995). Levers of Control: How Managers Use Innovative Control Systems to Drive Strategic Renewal, Harvard University Press: Boston.

Singh, D., Oberoi, J.S. \& Ahuja, I.S. (2012). Assessing strategic flexibility of manufacturing organizations using AHP. International Journal of Agile Systems and Management, 5(4), 319-329. http://dx.doi.org/10.1504/IJASM.2012.050153

Singleton, R. A. \& Straits, B. C. (2010). Approaches to Social Research, $3^{\text {rd }}$ edition, Oxford University Press: New York.

Smith, D.S. \& Langfield-Smith, K. (2004). Structural equation modeling in management accounting research: critical analysis and opportunities. Journal of Accounting Literature, 23(1), 49-86.

Smith, K. G. \& Grimm, C. M. (1987). Environmental variation, strategic change and firm performance: a study of railroad deregulation. Strategic Management Journal, 8(4), 363-376. http://dx.doi.org/10.1002/smj.4250080406

Smith, K.G., Grimm, C. M., Gannon, M. J. \& Chen, M. (1991). Organizational information processing, competitive responses, and performance in the U.S. domestic airline industry. Academy of Management Journal, 34(1), 60-85. http://dx.doi.org/10.2307/256302

Sproles, G. B. \& Kendall, E. L. (1986). A methodology for profiling consumers' decision-making styles. Journal of Consumer Affairs, 20(2), 267-279. http://dx.doi.org/10.1111/j.1745-6606.1986.tb00382.x

Stalk, G., Evans, P. \& Shulman, L. E. (1992). Competing on capabilities: the new rules of corporate strategy. Harvard Business Review, 70(2), 57-69. 
Steiger, J. H. (1990). Structural model evaluation and modification: An interval estimation approach. Multivariate Behavioural Research, 25(2), 173-180. http://dx.doi.org/10.1207/s15327906mbr2502_4

Teece, D.J., Pisano, G. \& Shuen, A. (1997). Dynamic capabilities and strategic management. Strategic Management Journal, 18(7), 509-533.

Thompson, J.D. (1967). Organizations in Action, McGraw-Hill, New York.

Tjosvold, D. (1991). Conflict within interdependence: its value for productivity and individuality. In Using Conflict in Organizations, DeDreu, C.K. and Van de Vliert, E. (Eds.), Sage Publications, London.

Treacy, M. \& Wiersema, F. (1993). Customer intimacy and other value disciplines. Harvard Business Review, 71, 84-93.

Ullman, J. B. (2001). Structural equation modeling. In Using Multivariate Statistics, Tabachnick, B.G. \& Fidell, L. S. (Eds.), 4th edition, Allyn and Bacon, Needham Heights.

Upton, D. (1995). What really makes factories flexible?. Harvard business review, 73(4), 74-84. http://dx.doi.org/10.1225/95410

Vandenbosch, B. \& Huff, S. L. (1997). Searching and scanning: how executives obtain information from executive information systems. MIS Quarterly, 21(1), 81-107. http://www.jstor.org/stable/249743

Van de Ven, A. H. (1986). Central problems in the management of innovation. Management Science, 32(5), 590-607. http://dx.doi.org/10.1287/mnsc.32.5.590

Virany, B., Tushman, M. \& Romanelli, E. (1992). Executive succession and organization outcomes in turbulent environments: an organization learning $\begin{array}{llll}\text { approach. } \quad \text { Organization } & \text { Science, }\end{array}$ http://dx.doi.org/10.1287/orsc.3.1.72

Volberda, H.W. (1998). Building The Flexible Firm: How To Remain Competitive. Oxford University Press, Oxford.

Walton, R. E. \& Dutton, J. M. (1969). The management of interdepartmental conflict: a model and review. Administrative Science Quarterly, 14(1), 73-84. http://www.jstor.org/stable/2391364

Weitzel, W. \& Jonsson, E. (1989). Decline in organizations: a literature integration and extension. Administrative Science Quarterly, 34(1), 91-109. http://www.jstor.org/stable/2392987

Widener, S. K. (2007). An empirical analysis of the levers of control framework. Accounting, Organizations and Society, 32(7-8), 757-788. http://dx.doi.org/10.1016/j.aos.2007.01.001 
Wiersema, M. F. \& Bantel, K. A. (1992). Top management team demography and corporate strategic change. Academy of Management Journal, 35(1), 91-121. http://dx.doi.org/10.2307/256474

Worren, N., Moore, K. \& Cardona, P. (2002). Modularity, strategic flexibility, and firm performance: A study of the home appliance industry. Strategic Management Industry, 23(12), 1123-1140. http://dx.doi.org/10.1002/smj.276

Yongsun, P. (1992). The impact of strategic flexibility on business performance in the international business environment. Journal of International Business Studies, 23(3), 591-592.

Zhang, M. J. (2005). Information systems, strategic flexibility and firm performance: an empirical investigation. Journal of Engineering and Technology Management, 22(3), 163-184. http://dx.doi.org/10.1016/j.jengtecman.2005.06.003

Zhang, M. J. (2006). IS support for strategic flexibility, environmental dynamism, and firm performance. Journal of Managerial Issues, 18(1), 84103. http://www.jstor.org/stable/40604526

Zhang, Y. \& Rajagopalan, N. (2010). Once an outsider, always an outsider? CEO origin, strategic change, and firm performance. Strategic Management Journal, 31(3), 334-346. http://dx.doi.org/10.1002/smj.812 


\section{APPENDIX: Variable Measurement}

Those items marked with an '*' are the retained items used in the SEM and reported in Table 2.

\section{Strategic flexibility}

1. Please indicate the extent to which the business unit has the capability to respond to each of the following:
a) *Resource reallocation requirements
b) *Emerging market opportunities
c) *Emerging market threats
d) Changing environmental conditions
e) Changing technology needs
f) The need to modify business partnerships (form/dissolve alliances, ventures, etc.)

\section{Strategic change}

2. Please indicate the extent to which the business unit has undergone change during the past 2 years with respect to:
a) *Business unit vision, mission, goals [structural and directional change]
b) *Restructuring [structural and directional change]
c) *The range of product/service lines provided [operational change]
d) *New technology adoption [operational change]
e) *Research and development [marketing change]
f) *Branding and marketing strategies [marketing change]
g) *Geographic coverage [marketing change]
h) *Product/service quality [product change]
i) *Product/service pricing [product change]
j) Business partnerships [operational change]
k) Distribution channels [operational change]
1) Financing of operations [operational change]

\section{Information characteristics (scope, timeliness, aggregation and integration)}

3. Please indicate the extent to which the business unit's information system has the following characteristics:
a) *Future-oriented information is provided [scope]
b) *External information is provided [scope]
c) Non-financial information is provided [scope]
d) *Information is delivered immediately upon request [timeliness] 
e) *Information is supplied to decision makers automatically upon its input into the information system or as soon as processing is completed [timeliness]

f) *Reports are provided frequently on a systematic, regular basis [timeliness]

g) *Information is provided for multiple time periods (daily, weekly, monthly, etc.) [aggregation]

h) *Information is provided on the effect of different departments' activities on the performance of the business unit [aggregation]

i) *Information is provided in formats suitable for input into decision models (e.g., discounted cash flow analyses, incremental/marginal analyses, "what-if analyses') [aggregation]

j) *There are precise targets for each activity performed in all departments within the business unit [integration]

k) *Information is provided on the impact that decisions have on the performance of all departments within the business unit [integration]

1) *Information is provided on the influence of other business unit managers' decisions on the business unit [integration]

\section{Interactive use of information}

4. Please rate the extent to which the business unit's management uses performance measures to encourage:

a) *Continual dialogue between superiors, subordinates and peers

b) *Continual challenge and debate of underlying data, assumptions and action plans

c) *Achievement of the business unit's objectives

d) *Focus on common issues

e) *Focus on critical success factors 